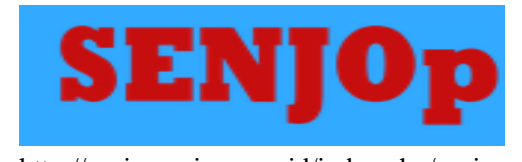

http://senjop.ppj.unp.ac.id/index.php/senjop

\title{
RIVER CARE COMMUNITY AND PADANG DISASTER EDUCATION PARK FOR DISASTER MITIGATION
}

\author{
* Rika Rubianti ${ }^{1}$ and Azmi Fitrisia ${ }^{2}$ \\ ${ }^{1}$ Master Program of Social Studies of Universitas Negeri Padang \\ ${ }^{2}$ Lecture Master Program of Social Science of Universitas Negeri Padang \\ e-mail: rikarubianti15@gmail.com \\ *Corresponding Author, Received: Augustus 14, 2019, Revised: October 17, 2019, Accepted: November 11, 2019
}

\begin{abstract}
This research is motivated to find out the survival of the Society survival in areas prone to landslides In The Village Of North Tandikek Patamuan Sub-District, Padang Pariaman District. Research location in the village of North Tandikek. This research uses qualitative approaches with case study research types, data collection techniques by observation, interviews and documentation. The selection of informant is done by Purposive Sampling. The Analysis of this research uses functional structural theory by Talcott Parsoons AGIL. The results of the research are that (1). The reasons for society to stay in the research site are: a). Environmental Factors, b) Economic Factors, c) Social Cultural Factors, d) Education Factors. (2). Society strategies for survival in landslide prone areas that is: a). Looking for a safe haven b). Greening empty land c). Mutual Cooperatin West Sumatra is one area with a high level of disaster vulnerability. West Sumatra BPBD said that West Sumatra was very vulnerable to natural disasters, and for most of the year natural disasters struck. The efforts made by the government in disaster management efforts in West Sumatra, especially in the city of Padang, were to establish a Disaster Education Park on the Purus Coast of Padang City. The Disaster Education Park aims to provide an understanding of disasters to the community, so that the community can prepare themselves for disasters. The purpose of this research is to describe the role of Purus Padang River Care Community and Disaster Education Park for disaster mitigation in Padang City. The method used in this study is a qualitative method with a descriptive approach. The results of this study concluded that there are several roles of the River Concern Community and Disaster Education Park in disaster mitigation efforts in the city of Padang, including: (1) Providing reading books as a source of knowledge about disaster, (2) Establish a River School, (3) Making KPS management a playground, (4) Providing Disaster Material / Training to the Community, (5) Monitor River Development, (6) Maintain the cleanliness of rivers, lakes and beaches.
\end{abstract}

Keywords: Disaster, Education Park, Mitigation 


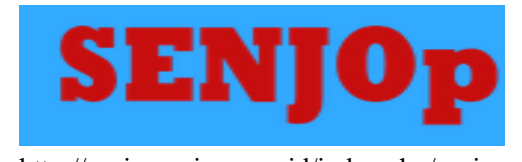

http://senjop.ppj.unp.ac.id/index.php/senjop
Science and Environmental Journals for Postgraduate

Vol. 2 No. 1 (pp. 39-46) December 2019

p_ISSN 2655-5085

e_ISSN 2655-5239

\section{INTRODUCTION}

One of the disaster-prone areas in West Sumatra Province is Padang City. Based on research conducted by EOS Nanyang Technological University Singapore and LIPI, Padang City is included in the list of areas that are expected to be the location of earthquake sources, as well as areas that will be affected by the tsunami which is expected to occur in the Mentawai Islands. Therefore, the city of Padang, which is the capital of the province, which has a high level of population density, is expected to be more alert to the threat of disasters that might occur at any time. To increase this awareness, efforts should be made to deal with disasters, known as mitigation (Hermon, 2017; Hermon, 2019). Where mitigation itself is a series of efforts to reduce disaster risk, both through physical development, and awareness in improving the ability to face the threat of disaster.

According to the Decree of the Minister of Home Affairs of the Republic of Indonesia No.31 of 2003, mitigation or taming is an effort and activity undertaken to reduce and minimize the consequences caused by disasters, which include preparedness and alertness. Mitigation is an obligation of various parties, both experts, the government, and the community itself, namely regarding the introduction and understanding of disasters, the process of occurrence of disasters, and the level of danger caused by disasters. Therefore, understanding, knowledge and preparedness need to be widely disseminated to the community so that disasters can be overcome and overcome, and the impacts caused by disasters can be minimized.

One form of efforts undertaken by the government to anticipate and cope with disasters is to establish Disaster Education Parks, Disaster Education Parks are reading parks managed by the Sumatra River Region V Office, and to empower communities to respond to disasters the Sumatra V River Region. to the River Care Community. The Disaster Education Park was built based on ideas from UNAND in collaboration with BNPB, IABI, SUMBAR PEMPROV, PEMKOT with support from the Ministry of PUPR and Sumatra River Basin Hall V (BWS SV) which has provided strategic infrastructure and location as public spaces to learn about disaster in Padang, serves as an introduction 


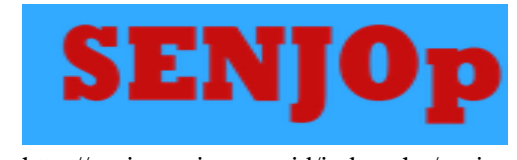

http://senjop.ppj.unp.ac.id/index.php/senjop
Science and Environmental Journals for Postgraduate

Vol. 2 No. 1 (pp. 39-46) December 2019

p_ISSN 2655-5085

e_ISSN 2655-5239

and education disaster to the community as one solution for disaster management that can occur at any time, especially in the city of Padang.

As an effort to campaign for preparedness and self-awareness of disaster risks in the city of Padang, this TEB developed a model for learning about disaster preparedness, one of which is Mural. The mural at this TEB depicts disaster events and makes us always remember the history of disaster events and increase awareness related to the disaster itself. How to change the mindset of the community so that they can care for one another, and care for the environment and be associated with the local cultural wisdom of the community (Hermon, 2015).

Disaster Education Park looks rarely visited by the community, even researchers often find the Disaster Education Park space in a closed condition, which means there is no one at the location. Meanwhile, to study the disaster books in this reading park, visitors are not charged anything, everything is provided free. But it seems that the Disaster Education Park itself is not very attractive in the eyes of the community, as seen from the number of visitors who come to read. If so of course what is expected from the disaster education park can not be realized as expected, therefore researchers want to see how the role of the River Concern Community in disaster management efforts in the city of Padang, especially in Purus City, Padang.

\section{METHOD}

This type of research uses the type of descriptive research, where data collected in the form of words, images and not numbers. This is due to the adoption of a qualitative approach. In addition, everything collected will be the key to what has been researched. Thus the research report contains quoted data to provide an overview of the presentation report. Data can come from interview manuscripts, field notes, photos, video tapes, personal documents, notes or demos, and other documents (Moleong, 2014). In accordance with the research topic that researchers did that what was revealed by the research informants was the main key in this study, namely the Role of River Care 


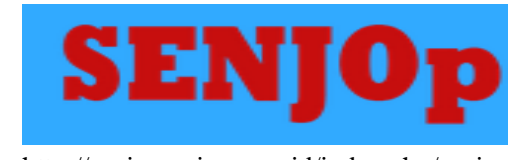

http://senjop.ppj.unp.ac.id/index.php/senjop
Science and Environmental Journals for Postgraduate

Vol. 2 No. 1 (pp. 39-46) December 2019

p_ISSN 2655-5085

e_ISSN 2655-5239

Community (KPS) and Purus Padang Disaster Education Park for disaster mitigation in Padang City. Data collection begins with direct interviews with Disaster Education Park managers as people who play an important role in building this Disaster Education Park, Disaster Education Park guards, as people who know more about the number and frequency of people visiting who come to park disaster education to learn books about disasters, after that Disaster Education Park visitors who have received lessons or direct knowledge from reading books in Disaster Education Park, and people who live in Purus Beach, Padang City as people who directly feel the existence of this Disaster Education Park .

\section{RESULTS AND DISCUSSION}

Disaster (disaster) is an event or excessive event that threatens and disrupts the normal activities of people's lives (Hermon, 2012; Hermon, 2014). In general, disasters occur as a result of human behavior, actions, influences, and anomalies caused by natural events (Sigit, 2018). The city of Padang is an area prone to disasters, therefore mitigation efforts are made to minimize the occurrence of such disasters, namely by establishing a disaster education park, which was established by the Ministry of Public Works PUPR in collaboration with the Sumatra River Region V Office, BNPB, the Provincial Government and City Government with the aim to provide a broad understanding to the public about disaster, where the community is expected to equip themselves with disaster knowledge. What preventive efforts must be done by the community, so that disaster can be avoided. And what are the efforts or things that must and can be done when a disaster occurs, and the efforts that must be made after a disaster can restore the community's condition as before. The Disaster Education Park is open to the wider community, especially the Purus community itself, as one of the disaster-prone areas. The books provided in the disaster education park include: (1) disaster resilient education (2) environmental pollution (3) SAR (Goes to School) (4) guidelines for implementing disaster preparedness training (Tsunami Drill) for Cities and Regencies (Hermon, 2016; Hermon, 2017). The role of the disaster education park as a disaster mitigation effort are: 


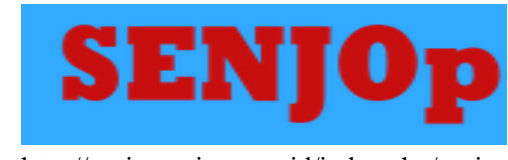

http://senjop.ppj.unp.ac.id/index.php/senjop
Science and Environmental Journals for Postgraduate

Vol. 2 No. 1 (pp. 39-46) December 2019

p_ISSN 2655-5085

e_ISSN 2655-5239

1. As one of the efforts in overcoming disasters, the role of the River Concerned Community and Disaster Education Park is to provide books on disaster for the community as a source of knowledge about disasters. Where the provision of disaster books is expected to the public to be able to use these books to increase community knowledge about disasters, both in prevention, preparedness and recovery. In addition to reading books about disasters, Disaster Education Park also provides educational games and pictures about disasters. So through pictures and games that children can learn the ins and outs of disaster, disaster prevention efforts, and efforts that can be done when a disaster occurs to save themselves and minimize the impact of disasters. Disaster Education Park is wide open to the public, where all levels of society can use the books that have been provided at the Disaster Education Park as reading material to increase knowledge about disasters. By providing books on disaster in the Disaster Education Park, it is hoped that the community will be able to use these books to increase community knowledge about disasters and increase awareness of disaster. So that the community participates in helping the government in disaster management, because disaster management is not only the responsibility of the government, but has become the responsibility of all levels of society, so it is expected that the government and all levels of society can jointly raise awareness of the dangers of disaster and efforts to reduce disaster risk for the sake of survival together. As revealed by the manager of TEB, who revealed that: "At TEB we provide books about disasters, there are murals about disasters and there are children's games that illustrate disaster as well, so the community or children who visit can read books so that it can increase public knowledge about disasters through these books or games ".

2. In addition to providing books on disaster, River Care Community (KPS) also established river schools. The intended river school is to provide students with knowledge of the river, how to preserve the river, and how to properly utilize the river. The invited students are elementary, middle, and high school students, because they will be the next generation who will guard the river later. The purpose of this river school is to provide students with knowledge of the river in order to maintain the river well, so that the existing river can benefit the community, then the cleanliness of the river must be maintained properly, namely by not throwing garbage and waste into the river, because it can damage the sustainability of the river and cause floods. These students were given material around the 


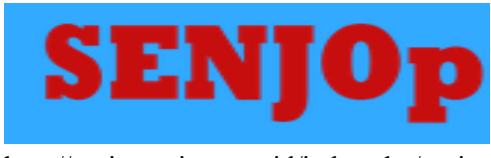

http://senjop.ppj.unp.ac.id/index.php/senjop
Science and Environmental Journals for Postgraduate

Vol. 2 No. 1 (pp. 39-46) December 2019

p_ISSN 2655-5085

e_ISSN 2655-5239

river, how to keep the river well maintained so as to prevent disaster, the cleanliness of the river can be maintained properly and the river can benefit the community.

3. Making the KPS Management Park (Disaster Education Park) as a Playground. The purpose of the Disaster Education Park is to empower the community for the realization of a disaster-aware community. Where in realizing it certainly requires cooperation from all parties and the wider community in supporting these activities. One of the ways carried out by KPS is by making the place that is managed (Disaster Education Park) as a playground. Because that way many people will come to visit Disaster Education Park to read books or just enjoy the beauty of the park that is served by this Disaster Education park, which of course with the many visitors to environmental cleanliness must be maintained properly. This situation is also used by KPS in empowering the community, especially children, because it will be easier to provide understanding for children to be able to protect the environment of rivers and lakes. One small thing that can be instilled in children is by inviting children to dispose of their leftover food waste into the rubbish bins that have been provided, as well as inviting children to pick up if there is trash littering around.

4. Providing Disaster Material / Training to the Community. In addition to providing understanding to children to protect the environment, KPS and other organizations also provide material / disaster training for the wider community, where the material or training provided is material about disaster, communities are introduced to rivers, lakes and seas, and the benefits we can get from these rivers, lakes and seas.

5. Monitor River Development. After providing material, understanding and training to the community, the next task for KPS is to monitor the development of rivers, lakes and seas to avoid damage, whether caused by human activities, or caused by nature itself. This is done so that the River Concern Community and other managers can make further prevention efforts to avoid things that can endanger the wider community, therefore the River Concern Community continues to monitor to ensure that rivers, lakes and other flows do not clogged to avoid standing water when it rains which can cause flooding resulting in material and non-material losses for the community and government. As stated by Mr. Dedi, FKPS secretary, he said: "Our next task is to monitor the progress of the river, and the flow of water. If there are obstacles that can be overcome as soon as possible, such as if there are rubbish that obstructs the flow of water we will immediately overcome, if we cannot overcome we discuss again with BWS or other forums, so that the problem can be resolved 


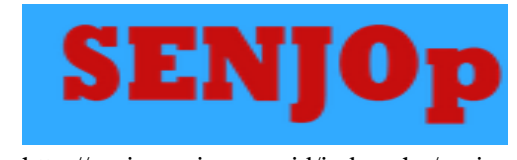

http://senjop.ppj.unp.ac.id/index.php/senjop
Science and Environmental Journals for Postgraduate

Vol. 2 No. 1 (pp. 39-46) December 2019

p_ISSN 2655-5085

e_ISSN 2655-5239

". Related parties such as the Sumatra V River Region, River Lovers Community (KPS), BPBD together with involving the community to clean up the coastal areas, rivers and Lake Cimpago from rubbish, this effort is one form of effort made by the parties involved in realizing The community is aware of disasters, and urges the community to protect and care for the environment by not throwing garbage into rivers, beaches or lakes. As stated by one informant, namely Mr. Rishael from BWS $\mathrm{V}$, who is also the manager of the Disaster Education Park who said that "one of the roles of this TEB as a disaster mitigation effort is by inviting the public to participate directly in cleaning up the environment around the Lake Cimpago and the coast, because that way the community can witness firsthand how the garbage scattered and floating in the rivers and the sea, and how difficult it is to clean the environment of these rubbish. So that by itself can be embedded culture of protecting the environment for the community itself ".

6. Maintaining Environmental Cleanliness (Rivers, Lakes and Seas). Maintaining environmental cleanliness (rivers, lakes and seas) is the main thing that is encouraged by KPS and other organizations and communities in creating a healthy environment, clean and free from disasters, or at least an effort that can be done in tackling disasters and minimizing the risks posed from disaster. Because a clean environment will provide invaluable beauty and provide a comfortable, peaceful atmosphere and provide a special attraction for tourists visiting the Purus region. If rivers and other waterways are free from rubbish, then one of the causes of the disaster can be overcome, because flooding is caused by overflowing water that reaches the surface, one of which is due to blocked waterways.

\section{CONCLUSION}

Providing reading books as a source of knowledge about disasters. As one means of efforts to tackle disasters, the role of disaster education parks is to provide books on disaster for the community as a source of knowledge about disasters. The availability of these books is expected to be used by the community to increase community knowledge about disasters and increase awareness of disasters. So that the community participates in helping the government in disaster management. Establish a River School. The intended river school is to provide students with knowledge of the river, how to preserve the river, and how to make good use of the river. 


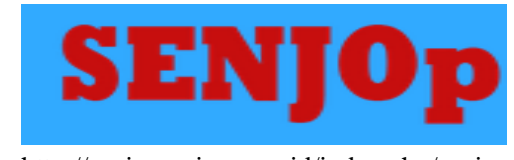

http://senjop.ppj.unp.ac.id/index.php/senjop
Science and Environmental Journals for Postgraduate

Vol. 2 No. 1 (pp. 39-46) December 2019

p ISSN 2655-5085

e_ISSN 2655-5239

\section{REFERENCES}

Abdullah, Mulat Wigati. 2008. Sosiologi untuk SMP dan MTs kelas VII. Jakarta: PT. Grasindo

Bungin, Burhan. 2010. Analisis Data Penelitian Kualitatif. Jakarta: Rajawali Pers

Hermon, D. 2012. Mitigasi Bencana Hidrometeorlogi: Banjir, Longsor, Degradasi Lahan, Ekologi, Kekeringan, dan Puting Beliung. UNP Press. Padang.

Hermon, D. 2014. Impacts of Land Cover Change on Climate Trend in Padang Indonesia. Indonesian Journal of Geography. Volume 46. Issue 2. p: 138-142. Fakultas Geografi Universitas Gajah Mada.

Hermon, D. 2015. Geografi Bencana Alam. Jakarta: PT RajaGrafindo Persada.

Hermon, D. 2016. Mitigasi Perubahan Iklim. Rajawali Pers (Radjagrafindo).

Hermon, D. 2017. Climate Change Mitigation. Rajawali Pers (Radjagrafindo).

Hermon, D. 2019. Mitigation and Adaptation: Disaster of Climate Change. Sara Book Publication. India.

Keputusan Menteri Dalam Negeri RI No.131 Tahun 2003 tentang Pedoman Penanggulangan Bencana dan Penanganan Pengunsi di Daerah Menteri Dalam Negeri

Khambali. 2017. Manajemen Penanggulangan Bencana. Yogyakarta: ANDI

Miles Matthew dan Huberman. A. Michael. 1992. Analisis data kualitatif. Jakarta: Universitas Indonesia.

Moleong, Lexy J. 2014. Metode Penelitian Kualitatif. Bandung: PT: Remaja Rosda Karya

Norris, Fran H dkk. 2008.Community Resilience as a Metaphor, Theory, Set of Capacities, and Strategy for Disaster Readiness

Rencana Kontijensi Menghadapi Bencana Tsunami Provinsi Sumatera Barat. UNDP

Sigit, Adityawan, dkk. 2018. Buku Pintar Mengenal Bencana Alam. Yogyakarta: CV. Budi Utama

Sugiyono. 2012. Memahami Penelitian Kualitatif. Bandung: Alfabeta.

Supriatna, Nana, dkk. 2006. Ilmu Pengetahuan Sosial (Geografi, Sejarah, Sosiologi, Ekonomi) untuk Kelas VIII Sekolah Menengah Pertama: Grafindo Media Pratama Undang-undang Republik Indonesia Nomor 24 Tahun 2007 tentang Penanggulangan Bencana

https://www.bnpb.go.id/taman-edukasi-bencana https://bnpb.go.id/uploads/24/rencana-kontigensi-tsunami-sumatera-barat.pdf www.padek.co 